\title{
Vliv nové podoby maturitní zkoušky z českého jazyka a literatury na vyučování ve výpovědích učitelů ${ }^{1}$
}

\author{
Stanislav Štěpáník \\ Univerzita Karlova v Praze, Pedagogická fakulta, Katedra českého jazyka
}

Redakci zasláno 28. 3. 2018 / upravená verze obdržena 15. 7. 2018 /

/ k uveřejnění přijato 23. 7. 2018

\begin{abstract}
Abstrakt: Cílem této empirické studie je prozkoumat vliv nové podoby maturitní zkoušky z českého jazyka a literatury (ČJL) na vyučování ČJL ve střední škole. Metodou polostrukturovaného rozhovoru s šestnácti učiteli gymnázií a středních odborných škol jsme zkoumali (1) jak a v čem konkrétně ovlivňuje (na základě výpovědí učitelů) podoba maturitní zkoušky vyučování ČJL na střední škole; (2) jak učitelé ČJL maturitní zkoušku z ČJL hodnotí a jak toto jejich hodnocení souvisí s jejich přístupem k vyučování a př́pravě na maturitní zkoušku. $Z$ výsledkủ vyplývá, že nový maturitní model přinesl některé pozitivní změny, avšak v některých ohledech jde proti požadavkům současné didaktiky českého jazyka i didaktiky literatury a také cílům vzdělávání obecně deklarovaným pro současnou školu.
\end{abstract}

Klíčová slova: washback, maturita, střední škola, český jazyk, vyučování, literární výchova, komunikační a slohová výchova, jazyková výchova

\section{Teoreticko-historický úvod}

Vliv zkoušky na vzdělávací systém a jeho účastníky není fenomén nový, v zahraničí je předmětem pedagogického výzkumu již několik desetiletí. Fakt, že zkouška ovlivňuje výuku, učitele, žáky i rodiče, jejich postoje, chování či motivaci, je obecně přijímaný (Pearson, 1988, cit. podle Alderson \& Wall, 1993, s. 115), stejně jako to, že vliv může být jak pozitivní, tak negativní (Green, 2013, s. 40).

V anglicky psané odborné literatuře se pro tento jev běžně užívá termínu washback (ve starších zdrojích backwash). Původně byl definován jako vliv

1 Př́spěvek byl zpracován $\mathrm{v}$ rámci projektu PRIMUS/HUM/19 Didaktika českého jazyka $v$ současném vzdělávacím kontextu, financovaného Univerzitou Karlovou a Pedagogickou fakultou Univerzity Karlovy. Autor děkuje za poskytnutou podporu. 
zkoušky na vyučování a učení (Pearson, 1988, cit. podle Alderson \& Wall, 1993, s. 115). Cheng, Sun a Ma (2015) v rámci důsledků, jež výsledky testů mají, rozlišují mezi pojmy washback a impact. Washback definují jako vliv zkoušky na výuku (vyučování a učení), impact jako široký vliv zkoušky, který sahá za hranice výuky (např. do vzdělávací politiky, vliv na společnost atd.); jinými slovy termín washback označuje mikropohled, zatímco impact makropohled. Rozšíření původní definice odpovídá faktu, že zkoušky jsou jedním z hlavních nástrojů vzdělávací politiky a vzdělávacích procesů v mnoha zemích (Cheng et al., 2015, s. 439); Česká republika v tomto není výjimkou. ${ }^{2}$ Vyjdeme-li ze zmíněné dichotomie mezi pojmy washback a impact, pak se v naší studii zabýváme, jak již název př́íspěvku napovídá, mikropohledem (washback), a to prizmatem středoškolských učitelů českého jazyka.

Stěžejní vliv na zkoumání washback efektu měla studie Aldersona a Wallové (1993), v níž je formulováno 15 základních hypotéz washbacku (washback hypotheses), jež další studie vztahující se k tématu rozpracovávají. K hypotézám patří např̀ to, že zkouška ovlivňuje vyučování a učení, konkrétně obsah i způsob vyučování, a tedy i obsah a způsob učení. Dále že ovlivňuje postoj účastníků vzdělávání $\mathrm{k}$ obsahu a metodám výuky. Podstatná je hypotéza, že čím větší závažnost zkouška má, tím větší je její washback. Dobrý test by měl podněcovat dobrou výuku, naopak špatně designovaný test učitele i studenty nutí k praktikám, které mají pouze omezenou vzdělávací hodnotu (Green, 2013, s. 41). Z hlediska jazykové výuky je toto stěžejní, nebot' - „čím větší jsou rozdíly mezi testovacími procesy a aktuálním, autentickým, reálně užívaným jazykem, tím větší je riziko škodlivého washbacku“(Green, 2013, s. 41; překlad S. Š.). ${ }^{3}$

2 Není naším cílem $\mathrm{v}$ tomto příspěvku rozebírat důvody, které stály za zavedením tzv. státní maturity v ČR. Na základě rozhovoru s M. Chválem, bývalým ředitelem Centra pro zjištování výsledků vzdělávání (později Cermat), však konstatujeme, že i u nás centralizace maturitní zkoušky byla užita jako nástroj vzdělávací politiky.

3 Markantní je to např́íklad u pravopisných úloh vyskytujících se v didaktickém testu. Vybíráme jeden příklad za všechny: „Mí přátelé se nedávno nachomýtli k vážné dopravní nehodě.“ (zadání z jara 2018); nejenže je př́́klad vykonstruovaný, nepřirozený a komunikačně nefunkční, ale ověřuje se zde znalost prostředku, který v současné živé češtině patří mezi zcela okrajové. Vyjmenované slovo nachomýtnout (se) se v korpusu SYN 2015 z celkového počtu cca 100 milionů textových slov vyskytuje celkem 47krát, v korpusu ORTOFON, který sleduje mluvený jazyk (cca 1 milion pozic), se dokonce nevyskytuje vůbec. To, že se tak okrajové jevy, zcela absentující v reálně užívaném jazyce, objevují v závěrečných zkouškách, má za následek, že výuka češtiny někdy dostává až archaizující ráz (srov. k tomu též např. Svobodová, 2003), a to již na 1. stupni ZŠ (vyjmenovaná slova jsou obsahem výuky ve 3. ročníku ZŠ). K další elaboraci tohoto problému v kontextu maturitní zkoušky z českého jazyka a literatury srov. Štěpáník a Šmejkalová (2017, s. 12-18). Upozorňujeme, že se však nejedná pouze o učivo pravopisné, ale také učivo gramatické. 
Dle Shiha (2009, s. 188-190; konkrétní doklady viz tento zdroj) z dosavadních výzkumů k tématu vyplývá, že:

- zkoušky jsou vždy příčinou změn obsahu výuky;

- zkoušky mají poměrně malý vliv na metody a formy práce ve výuce;

- zkoušky ovlivňují způsoby hodnocení ve výuce;

- zkoušky mohou být příčinou neetického jednání ze strany učitelů, a to jak ve fázi př́ípravy na zkoušku, tak i po zkoušce při její administraci (např. prozrazení otázek a zadání, manipulace s testy apod.);

- významné zkoušky mohou vést učitele k vyučování pouze pro zkoušku (teaching to the test);

- lekce připravující na zkoušku jsou primárně koncentrované na učitele (tzn. uplatňuje se model direktivně řízeného učení: učební aktivity jsou iniciovány a řízeny učitelem - srov. Maňák \& Švec, 2003, s. 17) ${ }^{4}$;

- zkoušky mohou činit vyučovací hodiny strukturovanější, ale méně zajímavé a dynamické;

- významné zkoušky jsou pro učitele zdrojem strachu a úzkosti;

- zkoušky neovlivňují všechny učitele stejně.

Základním paradigmatem diskuse je interakce mezi testem, vyučováním a učením. Zásadní roli v otázce míry a podoby washbacku má vždy učitel, a to jak v negativním, tak i pozitivním smyslu (Cheng et al., 2015, s. 464). Proto se doporučuje, aby součástí výzkumů k washbacku vždy byli učitelé (ibid.) odtud opodstatnění výběru respondentů v našem výzkumu.

Maturitní zkouška do školního roku 2016/2017 byla jedinou standardizovanou, státem garantovanou jednotnou zkouškou v našem vzdělávacím systé$m^{5}$ a historicky představuje zkoušku velmi významnou - „zkoušku dospělosti“. Lze ji označit jako rozhodnou zkoušku (z anglického high-stake), tedy jako zkoušku, jejíž výsledky mají pro zkoušeného významné důsledky. Je proto na místě předpokládat, že jakékoliv její změny mají na všechny aktéry školního vzdělávání u nás značný vliv.

4 Současné trendy ve vzdělávání přitom kladou důraz na aplikaci modelu výuky, „V němž je podporována ve větší míře aktivita, samostatnost a tvořivost žáků a který motivuje žáky k autoregulaci jejich učení" (Maňák \& Švec, 2003, s. 18).

5 Tou další se staly jednotné přijímací zkoušky. 
O maturitní zkoušce se mnoho diskutuje v médiích a na internetu, její reflexe v odborné komunitě je však minimální. $V$ pedagogických časopisech ${ }^{6}$ bylo k maturitě doposud publikováno jen několik diskusních příspěvků (Hrubý, 2015; Chvál, 2011; Jedlička, 2003; Kotáa, 2011; Skalková, 2000). V oborovědidaktických časopisech pro ČJL je maturita reflektována také převážně v diskusi - na stránkách Českého jazyka a literatury, stěžejního časopisu v didaktice češtiny, lze sledovat argumentaci pro novou podobu maturitní zkoušky (Soukal \& Skalská, 2011/2012), proti ní (Jeník, 2008/2009; Lippmann, 2011/2012, 2010/2011; Průžová, 2013/2014; Rysová, 2009/2010), příp. se autoři věnují jednotlivým aspektům zkoušky - Čechová (2013/2014) podobě slohové práce, Rysová (2013/2014) kritériím hodnocení slohových prací $\mathrm{s}$ důrazem na originalitu a invenčnost textu a časový limit pro slohovou práci, stejnému tématu se věnuje Kostečka (2012/2013), jenž ve svém příspěvku navrhuje kritéria hodnocení slohových prací, inspirovaná programem International Baccalaureate (IB). Rysová (2011/2012) upozorňuje na problémy cizinců při hodnocení maturitní zkoušky, především slohových prací, Soukal řeší tvorbu pracovních listů k ústní zkoušce (2010/2011) nebo sestavení kánonu literárních děl (2008/2009). Zajímavou a stále aktuální problematikou se zabývají Ibrahim (2013/2014) a Bílek (2001/2002), kteří upozorňují na množství narychlo vydávaných materiálů k přípravě k maturitní zkoušce, v nichž se vyskytují fatální chyby. Je cenné, že do diskuse na stránkách Českého jazyka a literatury přispěli převážně učitelé z praxe.

Jen zcela výjimečně (Jeník, 2008/2009, nebo Tabášek, 2007/2008) se autoři zabývají základní funkcí zkoušky ve vztahu k obsahu (a naopak) a důsledky navrhovaných změn pro výuku českého jazyka ve střední, ev. i základní škole. Na absenci tohoto pohledu v návrhu nové maturity upozornila už Skalková (2000, s. 275). Dá se ř́ci, že diskuse, jak byla a je vedena, potvrzuje, že „funkce vzdělávání mizí za formou testovacího zjištování" (Skalková, 2000, s. 278). Autorka kritizuje, že se pojetí maturity soustředilo primárně na technickou realizaci testů, nikoliv na představu o cíli, koncepci vzdělávání, o jeho smyslu a hodnotových preferencích.

V novodobých československých a českých dějinách mateřskýjazyk (u nás český jazyk a literatura) ${ }^{7}$ vždy tvořil jádro maturitní zkoušky (srov. Šmejkalová, 2010). Ta sestávala z ústní části a slohové práce. Slohová práce byla po vět-

\footnotetext{
Pedagogická orientace, Orbis scholae, Studia paedagogica, Pedagogika, e-Pedagogium

7 Někdy se silným vlastivědným akcentem.
} 
šinu času zadávána centrálně, obsah ústní zkoušky byl ponechán na školách, stejně jako hodnocení celé zkoušky. Předpokládalo se, že jazykové znalosti a dovednosti jsou ověřeny slohovou prací, proto obsahu ústní zkoušky většinou dominovala literatura.

V 90. letech byl model centrálního zadávání slohové práce opuštěn a do ústní zkoušky se na některých školách dostala také jazyková složka předmětu. Vzhledem $\mathrm{k}$ tomu, že zkoušky svou náročností mohly mít na různých školách různou podobu, již v polovině 90 . let se mj. na základě doporučení OECD objevily první diskuse o zavedení tzv. státní maturity, tedy zkoušky celostátně jednotné a zadávané centrálně. Na konci 90 . let proběhly různé pilotáže, např v rámci tzv. Sondy maturant. K definitivnímu uzákonění státní maturity došlo v roce 2004, novelou zákona z června 2007 bylo spuštění státní maturity odsunuto až na rok 2010, novelou z roku 2009 pak byl start státních maturit odsunut o další rok, tj. na školní rok 2010/2011. Na podzim roku 2010 proběhla tzv. maturitní generálka a na jaře 2011 proběhla maturitní zkouška poprvé $v$ nové podobě. Maturitní model i povinné předměty $v$ jeho rámci byly několikrát upravovány, avšak český jazyk a literatura v komplexní podobě testování (didaktický test, písemná práce a ústní zkouška) byly vždy zachovány.

Žádná relevantní výzkumná reflexe maturitní zkoušky doposud publikována nebyla, výsledky zkoušky zůstávají bez zevrubné a veřejně dostupné analýzy též ze strany Cermatu a ministerstva školství. Naším příspěvkem chceme přispět do diskuse o maturitách dílčím výzkumným zjištěním a upozornit na téma, které je pro náš vzdělávací systém zásadní, přitom však výzkumem opomíjené.

\section{Metodologie výzkumu}

Cílem této výzkumné studie je zjistit, jak učitelé nahlížejí na maturitní zkoušku v kontextu výuky ČJL na střední škole a jak se toto promítá do jejich práce. Zvolili jsme metodologii kvalitativního výzkumu, metodu polostrukturovaného rozhovoru. Vzhledem k tomu, že český pedagogický výzkum se problematikou washbacku v našem vzdělávacím systému doposud nijak nezabýval, vybrali jsme z hypotéz Aldersona a Wallové (1993, s. 120-121) ty, které se týkají učitelů a vyučování: 
1) Zkouška ovlivňuje vyučování.

2) Zkouška ovlivňuje, čemu učitelé vyučují.

3) Zkouška ovlivňuje, jak učitelé vyučují.

4) Zkouška ovlivňuje šířku a sled vyučování.

5) Zkouška ovlivňuje míru a hloubku vyučování.

Tyto hypotézy považujeme za tematický rámec našeho výzkumu. Podle něj jsme stanovili výzkumné otázky:

1) Jak a v čem konkrétně ovlivňuje dle učitelů podoba maturitní zkoušky výuku ČJL na střední škole?

2) Jak hodnotí učitelé ČJL maturitní zkoušku z ČJL a jak toto jejich hodnocení souvisí $s$ jejich přístupem k výuce a přípravě na maturitní zkoušku?

Otázkový soubor pro rozhovory s učiteli čítal celkem 13 otevřených otázek (viz Př́loha 1), z nichž ke čtyřem jsme respondentům poskytli škálu, abychom mohli i kvantitativním způsobem porovnávat převládající postoje mezi respondenty. Tazatelské schéma jsme vytvářeli s ohledem na tematický rámec a výzkumné otázky a tak, aby pokrylo všechny pomyslné aspekty, které zajímají oborového didaktika českého jazyka a didaktika literatury ve vztahu maturitní zkoušky a vyučování. Ptali jsme se na přípravu žáků na maturitní zkoušku z českého jazyka a literatury, hodnocení různých aspektů maturitní zkoušky z ČJL i jejích jednotlivých částí (náročnost, obsah, strukturu apod.), vztah respondentů k maturitní zkoušce a vliv maturitní zkoušky na jejich vyučování a způsob př́ípravy žáků na maturitu. Praktiků, kteří zažili maturitu před zavedením státní zkoušky, jsme se ptali na proměny v jejich vyučování a způsobu př́pravy na maturitu. Poslední otázka poskytovala respondentům prostor pro volný komentář, příp. jsme se dále doptávali. ${ }^{8}$ Pořadí otázek jsme volili tak, aby sledovalo trajektorii od obecnějšího ke konkrétnějšímu a střídalo náročnější otázky s otázkami méně náročnými.

8 Otázkový soubor jsme vyzkoušeli na jedné vybrané učitelce, naší dlouholeté kolegyni, upravený soubor jsme konzultovali na svém domovském pracovišti i na ÚVRV PedF UK. 
Oslovili jsme 40 češtinářů z různých státních středních škol v Praze a blízkém okolí, a to bud' osobně, nebo e-mailem. Výběr subjektů do vzorku probíhal tak, že jsme ze seznamu středních škol zřizovaných Magistrátem hl. města Prahy a Středočeským krajem náhodně vybírali z gymnázií, SOŠ a SOU se záměrem, abychom v každé kategorii měli přibližně shodné zastoupení. Dále jsme podle rozvrhů dostupných na webových stránkách jednotlivých škol vybírali učitele finálních ročníků. Cílili jsme na zcela běžné školy a standardní učitele, nebot' jsme usilovali o obvyklý obraz maturity na SŠ. V konečné fázi jsme oslovili 13 češtinářủ na gymnáziu, 13 na SOŠ a 14 na SOU či SOŠ-SOU.

Nejvyšší návratnost jsme zaznamenali od učitelů gymnázií, mizivou od učitelů středních odborných učilišt'. Někteří z oslovených učitelů byli naši současní či bývalí kolegové, s nimiž udržujeme přátelské vztahy. Návratnost u nich byla stoprocentní, ve výsledném vzorku tvoří čtvrtinu. Při setkání s jednou další respondentkou jsme zjistili, že jde o spolužačku z vysoké školy, čímž se míra familiarity vzorku ještě zvýšila. Jak se ukázalo, odpovědi těchto dotazovaných nám poskytly ještě důvěrnější vhled do problematiky. Na výzvu jsme obdrželi 21 reakcí, z nichž dvě byly zamítavé, zbývajících 19 učitelů projevilo ochotu se výzkumu zúčastnit. Tři učitelé svou účast ve výzkumu později přehodnotili.

Konečný vzorek tak čítal 16 učitelů z 11 různých škol: 12 žen, 4 muže; 9 učitelů gymnázia, 7 učitelů střední odborné školy9 ${ }^{9}$ Průměrná délka pedagogické praxe učitelů činila 17 let (nejnižší pedagogickou praxi měla učitelka s 5 odučenými lety, nejvyšší s 37 lety), většinově zastoupeni byli velmi zkušení praktici. Všichni učitelé připravovali maturitní třídy. Konkrétní podobu vzorku viz v tabulce 1.

Respondentům jsme vysvětlili cíl výzkumu, ujistili je o zachování důvěrnosti získaných informací a anonymním zpracování veškerých dat. Rozhovory jsme realizovali v průběhu ř́jna a listopadu 2016, byly zaznamenávány na diktafon, průměrná délka jednoho rozhovoru činila 24 minut. Záznamy byly následně přepsány.

Učitele SOŠ v textu dělíme do dvou kategorií, jak je patrné z tabulky 1: na učitele z teoreticky zaměřených SOŠ ( $v$ našem př́padě obchodní akademie a ekonomická lycea) a učitele z prakticky zaměřených SOŠ (v tomto výzkumu SOŠ zdravotnická a hotelová). 
Tabulka 1

Charakteristika výzkumného vzorku

\begin{tabular}{|c|c|c|c|c|}
\hline Učitel $^{10}$ & $\begin{array}{l}\text { Délka } \\
\text { pedagogické } \\
\text { praxe (v letech) }\end{array}$ & Typ školy & Škola & $\begin{array}{l}\text { Označení škol } \\
\text { v textu }\end{array}$ \\
\hline Sabina & 27 & gymnázium & \multirow{2}{*}{ A } & \multirow{9}{*}{ gymnázium } \\
\hline Barbora & 5 & gymnázium & & \\
\hline Beáta & 12 & gymnázium & \multirow{3}{*}{ B } & \\
\hline Robert & 7 & gymnázium & & \\
\hline Patricie & 18 & gymnázium & & \\
\hline Darina & 8 & gymnázium & $\mathrm{C}$ & \\
\hline Jaromír & 26 & gymnázium & $\mathrm{D}$ & \\
\hline Naděžda & 30 & gymnázium & $\mathrm{E}$ & \\
\hline Irma & 12 & gymnázium & $\mathrm{F}$ & \\
\hline Jolana & 16 & SOŠ - OA / EL & $G$ & \multirow{5}{*}{$\begin{array}{c}\text { teoreticky } \\
\text { zaměřené SOŠ }\end{array}$} \\
\hline Berta & 32 & SOŠ - OA / EL & $\mathrm{H}$ & \\
\hline Michal & 12 & SOŠ - OA / EL & \multirow{3}{*}{$\mathrm{CH}$} & \\
\hline Radka & 6 & SOŠ - OA / EL & & \\
\hline Denisa & 37 & SOŠ - OA / EL & & \\
\hline Boris & 10 & SOŠ hotelová & I & \multirow{2}{*}{$\begin{array}{c}\text { prakticky } \\
\text { zaměřené SOŠ }\end{array}$} \\
\hline Daniela & 13 & SOŠ zdravotnická & $\mathrm{J}$ & \\
\hline
\end{tabular}

Data jsme analyzovali v kontextu didaktiky českého jazyka a didaktiky literatury, tedy dle okruhů, které jsou podstatné pro aktéry jakkoliv angažované ve vzdělávacím oboru český jazyk a literatura. Základní zkoumané okruhy byly: Co pro učitele znamená maturita, Ke koncepci maturity, Př́íprava na maturitu, Jazyk, Komunikace a sloh, Literatura, Maturita a výuka. Tato soustava pokrývá také hypotézy uvedené výše a posloužila jako rámec pro zobecnitelné přesahy získaných dat.

Data jsme analyzovali v programu MAXQDA. Postupovali jsme nejprve dle stanovených okruhů, ty tvořily první sadu kódů. Po rozdělení dat do okruhů jsme je podrobili druhému kódování, tentokrát jsme přiřazovali kódy uvnitř jednotlivých okruhů, vznikly tak podrobnější kategorie. První sada kódů tedy byla předem daná, druhá vyvstala $\mathrm{z}$ analyzovaných dat. $\mathrm{V}$ konečné fázi tedy vzniklo dvouúrovňové kódování, např. Maturita a výuka - maturita jako faktor změny obsahu.

10 Jména byla změněna. 


\section{Výsledky výzkumu}

Následující výklad segmentujeme podle jednotlivých okruhů, jichž se učitelé v rozhovorech dotýkali a jež vychází ze struktury výsledného kódování.

Maturita má v životě středoškoláka významnou roli. Je vyvrcholením jeho studia, dokladem pro zaměstnavatele i základním formálním předpokladem pro studium na vysoké škole. I naši respondenti jí připisují značnou váhu, a to i ti, kteří se k její současné podobě staví kriticky. Představuje pro ně završení studia, cíl ${ }^{11}$, k němuž čtyři roky směřují, zároveň však také velký stres. Lze říci, že učitelé „žijí“ maturitu společně se svými žáky. Považují ji za iniciační rituál, zkoušku zralosti, má velký význam z hlediska psychologického a sociálního. Všichni respondenti, i ti, kteří mají k současnému nastavení maturitní zkoušky negativní postoj, považují maturitu za velmi významnou zkoušku.

Maturitní zkouška historicky představuje jeden ze základních mezníků v naší vzdělávací soustavě, je významná z pohledu společnosti i učitelské veřejnosti. Učitelé přirozeně chtějí, aby jejich žáci byli u zkoušky úspěšní. Naši respondenti v tomto nejsou výjimkou - všichni vypovídají, že své žáky specificky/cíleně k maturitě připravují.

\subsection{Ke koncepci maturity}

Maturitní zkouška z českého jazyka a literatury je koncipována jako komplexní. Oslovení učitelé považují za nejnáročnější ústní část, následuje didaktický test a slohová práce. Jeden gymnaziální učitel, který maturitní zkoušku v současné podobě hodnotil velmi kriticky, uvedl, že žádnou z částí nepovažuje za náročnou. Jde spíše o pohled výjimečný. Oslovení respondenti většinově považovali nároky maturitní zkoušky z ČJL za přiměřené, většinou se jednalo o učitele gymnázia a teoreticky zaměřených SOŠ. Čtyři gymnaziální učitelé uvedli, že zkoušku pocitují jako spíše či velmi snadnou, jeden vyučující prakticky zaměřené SOŠ ji považuje za spíše náročnou. Hodnocení náročnosti maturitní zkoušky se tedy různí a jsou odvislá primárně od typu školy a úrovně jejích žáků.

S hodnocením přiměřené, ev. nízké náročnosti souvisí pohled mnohých učitelů gymnázií a teoretičtějších SOŠ, že jednotná zkouška pro všechny maturanty vede k úpadku motivace jejich žáků ke studiu:

11 Ve výpovědích učitelů v plné míře zachováváme obsah, prováděli jsme pouze formální úpravy. 
Jak oni to podle mě vnímají jako spíše snadné, tak velmi podceňují tu př́ípravu, si myslím. Takže ve finále to vnímají jako že čeština, to dá prostě každý, ale potom ta znalost je velmi povrchní. (Barbora)

Možná že bych se vůbec nebránila udělat tu zkoušku ještě o něco obtížnější, protože jestliže maturita má prokázat, že student, řekněme, je hotový člověk, když to řeknu jako velmi neotesaně, tak by ta maturita neměla být udělatelná pro každého, a já se bohužel obávám, že v dnešní době ta maturita je téměř udělatelná pro každého. (Radka)

Zkušená gymnaziální učitelka Sabina shrnula (nejen) svůj pocit takto: „Tam se neprojeví ti opravdu hodně šikovní studenti, je to prostě pro ně hodně omezující a skutečně dává pouze průměrný obraz toho maturanta; prostě průměr." Z opakujícího se hodnocení tohoto typu u gymnaziálních učitelů lze říci, že pocit’ují náročnost maturity z ČJL jako nastavenou na průměrného žáka, čímž podle nich vede $\mathrm{k}$ průměrnosti. Pocitovaná stoupající náročnost (především faktografická) jim proto vyhovuje:

Poslední dva roky, kdy ty didaktické testy se mi zdají trošku náročnější... Mně právě vadilo svého času, ty první roky, že to bylo takový jako inteligenční test na nějaké jazykové kompetence, dejme tomu, nebo na práci s textem. Ale ted’ se mi právě docela líbí, že tam chtějí přece jenom i nějaké ty faktografické znalosti. (Michal)

Naopak učitelé z prakticky zaměřených SOŠ udávají, že mají potíže zvládnout veškeré učivo ve vymezené časové dotaci, a navíc se potýkají s tím, že ČJL nepatří k prioritám žáků těchto škol a jejich motivace ke studiu je celkově nízká. ${ }^{12}$ Domníváme se, že z tohoto rozporu by bylo možné usoudit, že identická zkouška pro všechny střední školy se jeví spíše jako problematická.

Někteří respondenti nastavení maturitní zkoušky vnímají jako omezující: „Kdybychom nemuseli připravovat na tohle, tak bychom je určitě naučili daleko víc." (Jaromír). Ve výpovědích učitelů se často objevuje motiv nejasného cíle maturity, chaosu (spojený zvláště s prvními roky zkoušky), finanční i organizační náročnosti, přehnané byrokracie:

Opravdu se tam hraje na minuty, i ta terminologie je taková vojenská. (Irma)

Prostě to jsou opravdu křeče v břichu, abychom to stihli, to fakt koukám na ty hodiny, deset minut todle, pět minut todle, abychom se dostali dál, abychom teda projeli, aby pak nikdo neřek', že tenhle to tam neříkal a tenhle to říkal. (Jolana)

12 Tato konstatování jsou v souladu s výsledky výzkumu Krejčové (2009). 
a různých formálních požadavků, které považují za zbytečné - to se nejmarkantněji týká povinné struktury ústní zkoušky. Výstižně to shrnuje učitelka Patricie:

A myslím si, že to je strašnej dril a že tam je jako obrovská disproporce mezi tím, co se na jednu stranu jakoby po nás chce; to je problém současnýho školství. Ten spočívá $\mathrm{v}$ tom, že na jednu stranu my jako máme učit velice progresivníma metodama, máme rozvíjet úplně jakoby jiný dovednosti v těch dětech, aby se uplatnily $\mathrm{v}$ životě, zaostáváme za západním školstvím pořád ještě podle těch výzkumů, a na druhou stranu jako pak, když dojde na lámání chleba a oni mají vyplňovat tydlety testy, tak vlastně tam po nich chtěj' ale naprosto jako jasný znalosti, znalosti se po nich chtěj', jo? Takže kde to jsme? Tak my jsme takoví jako dezorientovaní, my jako na jednu stranu se snažíme vopravdu se sami učit, abychom se naučili učit jinak, a na druhou stranu jsme v kleštích s tímdle tím.

Mnohým osloveným učitelům chybí „lidský rozměr“ zkoušky, ohled na individuální potřeby žáků (zvláště palčivý se ukazuje problém žáků-cizinců ${ }^{13}$ ). Zvláště poslední zmíněný aspekt se ukazuje dosti zásadně: Čtyři roky se učitelé se svými žáky setkávají ve sdíleném prostoru, vytvářejí mezi sebou významný lidský vztah (učitel je jedním z důležitých druhých lidí - Čáp, 1993, s. 326), vedou své žáky $\mathrm{k}$ „velkému finále“ s vědomím, že se v něm společně setkají. Avšak od učitele se zde vyžaduje změna perspektivy, jakési „odlidštění" a šablonovitost. To námi oslovení češtináři nesou nelibě.

Respondenty jsme požádali, aby maturitní zkoušku jako celek zhodnotili klasifikačním stupněm jako ve škole a své hodnocení zdůvodnili. Průměrné hodnocení za všechny respondenty je 3,0, konkrétní argumenty jsou zakomponovány $\mathrm{v}$ dalším textu.

\subsection{Př́prava na maturitu}

Příprava na maturitní zkoušku představuje pro oslovené učitele nevyhnutelnou součást jejich práce, za úspěch žáků u maturity se cítí zodpovědní. Vnímají tlak rodičủ i médií a formální tlak ze strany vedení, které chce,

13 Na problém žáků-cizinců a státní maturity poukázala Rysová (2011/2012). Potíže žákůcizinců potvrzují i naši respondenti - přestože cizinci česky umějí a bez problémů by dle učitelů zvládli studium na vysoké škole, překonání didaktického testu nebo slohové práce ve stanoveném časovém limitu pro ně představuje problém. S centralizací hodnocení písemné práce se obavy učitelů o žáky-cizince stupňují, protože se strachují, že nebude nijak přihlíženo k individuálním dispozicím jednotlivých žáků: „a když my tohodletoho člověka, který tady bude žít, mu neumožníme to vysokoškolské vzdělání, na které on evidentně má, tak co z něj bude?" ptá se jedna z respondentek. 
aby škola měla co nejlepší výsledky. Cílené/specifické přípravě k maturitní zkoušce proto připisují veliký význam, většina respondentů považuje přípravu s učitelem za klíčovou, udávají, že žáci nejsou schopni se připravit sami - nejen z důvodu formy a obsahu zkoušky, ale i z důvodu jejich nedostatečných osobních dispozic.

Mnozí dotazovaní, kteří zažili i necentralizovaný model maturitní zkoušky, přiznávají zvýšené množství specifické přípravy k maturitě:

Připravujeme bohužel v posledních letech hodně specificky, hodně cíleně. (Berta)

Člověk by rád měl širší záběr, ale hodně času nebo víc času, než jsem byla zvyklá, jsem musela v posledních letech věnovat právě té př́ípravě na maturitní zkoušku, že opravdu jako to byl cíl, místo aby to byl jeden z cílů třeba. (Denisa)

Dřív se daleko intenzivněji učilo, ted' se daleko intenzivněji připravuje. (Jaromír)

Tyto výroky lze dát do souvislosti se dvěma skutečnostmi:

1) Původní maturitní model nevyžadoval takřka žádnou přípravu na formální náležitosti zkoušky. Z našich rozhovorů vyplývá, že všichni respondenti považují za jeden ze současné přípravy žáky právě na tyto aspekty (obsah, struktura, požadavky, kritéria hodnocení apod.), seznamují je také s patřičnými formuláři a pravidly zkoušky (průběhem apod.):

Ta metodika toho kladení otázek a ten způsob těch dotazů je u toho didaktického testu docela důležitý, aby si prostě zvykli na to, jak ty didaktické testy vypadají, jakou mají strukturu, jaký způsob myšlení to vlastně chce, jak hledat v textu, čemu se vyhnout, takže to pak opravdu narůstá v tom čtvrtém ročníku. (Michal)

Nicméně ty typy úloh, které didaktické testy nabízely, tak ty zkoumáme, upozorňujeme, jak jsou formulovány nebo jak jsou nastavené, sestavené ty úlohy, čeho si všímat, dávám doporučení, všímejte si, co je a co není předmětem zájmu tohoto zadání a tak, kolik má bodů ta úloha, nějaká strategická doporučení. (Denisa)

Cíl je zřejmý: nechtějí, aby žáci neuspěli kvůli tomu, že by se nevyznali ve formálních atributech zkoušky. Nevyhnutelnou součástí vyučování našich respondentů se tak staly nácvik zkouškových strategií a práce s testy z uplynulých ročníků nebo se specializovanými př́ručkami $\mathrm{k}$ maturitě ${ }^{14}$, někteří oslovení učitelé přistupují také k nácviku ústní zkoušky formou simulace.

14 Jejich kvalita může být dosti různá, někdy pochybná, či dokonce zcela vadná - srov. Ibrahim (2013/2014) nebo Bílek (2001/2002); na obdobný problém, avšak v případě přípravných materiálů k jednotným přijímacím zkouškám, jsme upozornili in Štěpáník (2016/2017). 
2) Na rozdíl od původního modelu maturitní zkoušky má současná maturita jasně stanovený obsah i předem daná kritéria hodnocení. Oslovení učitelé velmi dbají na to, aby skutečně splnili vše předepsané, hlídají, zda probrali všechno, co je předepsáno v katalogu požadavků k maturitní zkoušce ${ }^{15}$. Jak vypovídá Radka: „Odškrtávám si v tom seznamu, abych opravdu nic nevynechala. Je to seznam na stránkách Cermatu a jsou tam směry a autoři, kteří by mohli jít v didaktickém testu." Respondenti také pečlivě sledují, zda se obsah katalogů nezměnil.

Kontrastujme nyní uvedený výrok s výrokem Sabiny, která zažila i původní model zkoušky: „Minulá maturita, ta pro mě byla daleko lepší - vzpomínám na staré časy, ten dialog se rodil tam." Srovnání obou výroků lze číst tak, že zatímco dříve byla v popředí výuka a maturita stála na konci spíše jako vrchol středoškolského vyučování a učení, nyní vystupuje hned od začátku do popředí maturitní zkouška a výuka je intenzivněji vnímána jako prŕprava na ni. ${ }^{16}$

Jak z rozhovorů vyplývá, tento efekt však nemusí souviset jen s nastavením maturitní zkoušky, ale i s pocitovanou klesající úrovní žáků, kteří nastupují ke studiu na středních školách.

Mnozí z oslovených učitelů přiznávají, že svým žákům dávají ke zkoušce strategická doporučení. Např vybraným žákům radí konkrétní knihy do seznamu četby k ústní části nebo slohové útvary k písemné práci, o nichž se domnívají, že by je daný žák mohl úspěšně zvládnout:

V tom čtvrtáku se netajím tím, že některé hodně směruju, co ano a co ne. Třeba opravdu byli studenti, kdy jsem jim ř́́kala: „Nepište úvahu, prostě vy na to nemáte, je mi to líto. Snažili jsme se ji nějak vytř́íbit, ale prostě není to tam." Takže tam je i takto manipuluju. (Barbora)

Tento fenomén učitelé dávají do spojitosti s touhou po úspěchu žáků a také se ztrátou „lidského“ rozměru zkoušky, kdy u centrálního hodnocení slohových prací panuje nejistota, jak je bude externí hodnotitel posuzovat (srov. dále).

Někteří oslovení učitelé se věnují přípravě na maturitní zkoušku i nad rámec svého úvazku, ve volném čase, z čehož opět vyplývá, jaký význam maturita

15 Viz http://www.novamaturita.cz/katalogy-pozadavku-1404033138.html, cit. 29. 9. 2017.

16 Takřka polovina respondentů udává, že ve 4. ročníku vydělují jednu hodinu z celkové týdenní dotace na př́ípravu k maturitní zkoušce. Některé školy dále doplňují hodinovou dotaci volitelnými semináři speciálně cílenými na přípravu k maturitní zkoušce. 
$\mathrm{v}$ životě střední školy má a jak moc učitelům záleží na tom, aby jejich žáci byli úspěšní:

Já jsem ho (žáka-cizince - pozn. S. Š.) učila celé prázdniny a ted' se se mnou stř́ídá paní ředitelka. (Patricie)

Připravuju jim materiály navíc, které jim posílám e-mailem. (Daniela)

Podmínkou klasifikace v každém pololetí je, že si vyberou z kánonu děl k maturitní zkoušce dílo z určitého vymezeného období a potom si se mnou domluví termín na zkoušení, když to mají přečtené a jsou připraveni. Přinesou knihu, otevřeme na nějakém místě, přečteme si oba stránku nebo více stránek z různých míst a povídáme si o té knize. Padnou otázky vlastně jako u té ústní části maturitní zkoušky. To dělám mimo svoji výuku. (Beáta)

Výrazné vystupování maturitní zkoušky do popředí lze dát do souvislosti i s tím, že takřka polovina dotazovaných udává, že s cílenou přípravou k maturitě začíná již v 1. ročníku. Bohužel nemáme žádná data, která by nám řekla, kdy učitelé začínali s cílenou přípravou v původním modelu, nicméně na základě vlastní čtrnáctileté pedagogické praxe (z toho 11 let na SŠ) usuzujeme, že by se odpovědi setkaly spíše na tom, co udává zkušenější polovina našeho vzorku: 3. ročník, a ještě spíše 4. ročník. Všichni respondenti se nicméně shodují v tom, že nyní se př́prava k maturitě v různých podobách promítá do celého studia. Nemusí mít přímo formu explicitní, ale jaksi „podvědomou“, implicitní, což popisují následující výroky:

Po celou tu dobu studia se snažíme připravovat je i s ohledem na ten cíl, který všechny čeká. (Radka)

Tak jako to, jak ta maturita vypadá, já to vím a samozřejmě ty kroky nebo ty metody výuky tomu do určité míry přizpůsobuju. $S$ tím ale, že necítím, že by to bylo šroubovaně, že by to bylo nepřirozeně. (Barbora)

Řekla bych, že už od těch nejnižších ročníků, od primy, opravdu směřujeme jak $\mathrm{k}$ těm didaktickým testům, tak ke slohům, tak i k té ústní části. (Darina)

To se např. odráží v tom, že někteří oslovení učitelé formulují otázky do svých písemných prací formou zadání didaktického testu, tedy jako uzavřené úlohy $\mathrm{s}$ výběrem odpovědí, příp. zadávají slohové práce dle témat $\mathrm{z}$ minulých maturitních ročníků.

Příprava může být dokonce utajená, skoro až „ilegální“. Učitelka Daniela k prŕpravě na maturitní zkoušku vypověděla toto: 
D: My dokonce máme od vedení zadáno, že nesmíme opakovat k maturitě, my musíme jet tematický plán.

S. Š.: A když to podle tematického plánu nadepíšeš do tř́ídnice, děláš to (myšleno opakování k maturitě - pozn. S. Š.)?

D: Sama.

S. Š.: Jestli to ty teda neoficiálně děláš.

D: Hm.

S. Š.: Děláš.

D: Hm.

S. Š.: A kolik?

D: No, hrozně moc.

Toto důvěrné sdělení poukazuje na určitý rozkol, jemuž mohou být někteří učitelé v praxi vystaveni. Na vnitřní boj, jenž svádějí. Na jedné straně je to tlak výuky a na druhé straně zodpovědnost za úspěch žáků u maturitní zkoušky. Náš vzorek není dostatečně velký na to, abychom mohli informaci generalizovat, ale $\mathrm{z}$ výpovědí našich respondentů usuzujeme, že tomuto rozštěpení jsou vystaveni spíše učitelé na SOŠ, zvláště pak praktického zaměření, a to z důvodu nižšś znalostní úrovně budoucích maturantů. Dle priority takových učitelů může čas vyučování naplno opanovat př́íprava na maturitní zkoušku, zatímco výuka ustupuje do pozadí.

\subsection{Složka jazyková}

Hlavním cílem středoškolského studia češtiny je aktivní, praktické ovládnutí kultivované komunikace prostředky přiměřenými funkci a situaci projevu, jež zahrnuje i vertikální rozlišení výraziva a jeho diferencované užívání (co do jeho spisovnosti, stylovosti, expresivnosti, frekvence a „dobové příchuti“) (Čechová, 2017, s. 213).

Důraz je kladen na komunikační činnosti a požaduje se funkční přístup k probíranému učivu. Jde o operace kognitivně náročné, které slučují probírané jazykové jevy do vzájemně provázaného systému. Teoreticky by se mělo ve středoškolské výuce českého jazyka dospět nejen k hlubokému poznání tzv. bázových jazykových disciplín (mj. fonetiky, morfologie, syntaxe, lexikologie a slovotvorby), ale poznávání jazyka by mělo pokročit dále $\mathrm{k}$ perspektivám např. pragmatickým, sociolingvistickým, dialektologickým, historickým apod. Letitý problém středoškolské výuky českého jazyka však bohužel představuje opomínání jazykové složky předmětu (srov. Čechová, 2011/2012; Kostečka, 2001/2002; Machová, 2003/2004; 
Soukal, 2005/2006, ad.). Chybí tak rozvoj náročných myšlenkových operací. Obsah středoškolského jazykového učiva ve velké míře kopíruje obsah učiva základní školy (srov. Rysová, 2005/2006) a zmíněné obsahy nejsou ani předmětem maturitní zkoušky (srov. katalog požadavků - Cermat, 2014), ačkoliv v kurikulu i v obsahu některých učebnic se selektivně vyskytují.

Ani námi oslovení učitelé se většinově mluvnici příliš nevěnují, předpokládají její zvládnutí z předchozí etapy vzdělávání. Patrná je preference slohové a literární výuky, a to i z toho důvodu, že jazyková výchova působí př́liš akademicky, zkostnatěle, neprakticky (srov. Rysová, 2005/2006; Štěpáník, 2016; Zimová, 2005/2006, ad.). Svým výrokem to ilustruje učitel Robert: „Musím říct, tam u té mluvnice jsem zatím nedospěl k ničemu, co by bylo na podobném principu jako $v$ těch hodinách literatury." - tj. komunikační pojetí literární výchovy (srov. Hník, 2014; Lederbuchová, 2002/2003, 2010). Lze tedy usuzovat, že v praxi dochází k separaci požadavků (i) maturitní zkoušky, reprezentované katalogem požadavků, (ii) projektovaného kurikula, představovaného RVP a učebnicemi, a (iii) moderní didaktiky českého jazyka (srov. též dále).

Zvládnutí jazykové složky předmětu má primárně prověřovat didaktický test. Ten někteří respondenti chválí, nebot' klade důraz na práci s textem, učinil jazykovou část předmětu povinnou složkou maturitní zkoušky a přitom se nesoustředí pouze na testování mluvnické teorie:

Ten didaktický test se mi líbí, musím říct. [...] komplexní čtení s porozuměním tam je, jsou tam zastoupeny ty jednotlivé jazykové disciplíny, já prostě nemám s tím didaktickým testem problém. (Barbora)

Některým osloveným učitelům se však jeví jako nevyzpytatelný:

Nejhorší je taková ta prostě nejistota. Nevíte, na co je máte připravovat, jo, protože je to strašně široký rozsah v tom didaktickém testu. (Boris)

Všichni vyučující tady jsme se shodli, že vlastně nevíme, co ten Cermat bude sledovat. (Jaromír)

Maturita, která prostě opravdu pro ně vypadá jako loterie. (Jolana)

A co do náročnosti nevyrovnaný: Myslím, že Cermatu se vůbec nedaří držet nějakou vyrovnanou úroveň, jo? (Jaromír)

Podle mě náročnost toho didaktického testu spočívá $v$ tom, že $v$ jeho jakoby nevyrovnanosti. (Boris) 
Tato hodnocení jsou patrná u učitelů, kteří k současné podobě maturitní zkoušky mají největší výhrady a nevnímají ji př́liš pozitivně. Jsou sice založená na reálném základu (srov. poněkud chaotické začátky maturity po jejím spuštění a následný vývoj), avšak přetrvávají z minulosti. Situace se, jak i z některých výpovědí jiných respondentů vyplývá, stabilizovala:

Pokud jde o ten didaktický test, tak v těch posledních letech, třeba dvou, se mi líbí, že tam se mi zdá, že je vyvážený. Ty námitky, které se objevují, jsou víceméně jako nesmyslné, že to prostě je vytržené z kontextu. (Michal)

Největší problém se zmíněnými negativními aspekty didaktického testu se ukazuje u učitelů v praktičtěji zaměřených SOŠ, kteří přiznávají, že je těžké s žáky test „nacvičit“. Jistá nevyzpytatelnost je však u testu - jako u každé zkoušky - nutná.

\subsection{Složka komunikačně-slohová}

Tradičně výuka komunikačně-slohové výchovy na ZŠ vychází od slohových útvarů, na SŠ z teorie funkčních stylů, přičemž se uznává, že vztah mezi vzájemně propojenými funkčními styly a slohovými útvary je poměrně složitý (srov. Čechová \& Styblík, 1998). Teorie funkčních stylů nemůže být jediným východiskem a kritériem slohového vyučování, protože „čisté funkční styly“ nepokrývají veškerou verbální komunikaci; hlavním hlediskem výuky je hledisko komunikační, a to ve vztahu k autorovi i adresátovi projevu (ibid., s. 200). Funkční styly však tradičně tvoří základ středoškolské výuky slohu proto, že jde o pojmy vyšší roviny obecnosti než slohové útvary (srov. též obsah učebnic), čímž se blíží kognitivní vyspělosti středoškoláků.

Většina učitelů vypověděla, že v komunikačně-slohové výchově postupuje podle slohových útvarů, funkční styly jako východisko zmínili učitelé jen zcela ojediněle:

Procvičujeme ty jednotlivé útvary. (Radka)

Ta výuka jde prostě po útvarech, ačkoliv teda chci, aby chápali, co je to funkční stylistika. (Barbora)

Jinak hodně trénujeme právě ty útvary. Jak na práci s texty cizími, aby viděli, jak ten útvar vypadá, tak potom taky aby opravdu byli schopní i říct abstraktně, co teda ten útvar chce, a ne jenom to umět napsat. Ale opravdu svým způsobem biflování. (Darina) 
Tak tam řeknu, dobře, prostě máme, nebo Cermat má tyto parametry [sic! pozn. S. Š.] pro vyprávění, vy to máte vědět, měli byste si to zkusit, je tam tohle, tohle, tohle a to se hodnotí. (Jolana)

Aby uměli spíš jenom pár těch útvarů, ale pořádně [...], takže „drtím“ úvahu, „drtím“ popis, „drtím“ motivační dopis, ale „nedrtím“ už třeba fejeton nebo odborný popis. (Daniela)

Nemyslím, že bych vychovávala budoucí autory kuchařek, aby museli psát recepty a tak podobně. Myslím, že ten sloh by měl být trošku něčím jiným, než je učit takovéhle útvary, to se mi zdá docela zbytečné. [...] Mám větší odvahu nutit je k tomu, že opravdu budeme muset analyzovat texty všech možných funkčních stylů. (Beáta)

Z množství výpovědí dotazovaných lze usoudit, že maturitní zkouška ovlivnila způsob výuky slohu na střední škole v samé podstatě, a to tím způsobem, že narušila postup dle funkčních stylů.

Základní příčinou této změny jsou jednotná kritéria hodnocení písemné práce vydaná Cermatem, konkrétně kritérium 1 - Vytvoření textu podle zadaných kritérií (text se vztahuje k zadanému tématu, vykazuje charakteristiky zadaného útvaru a odpovídá zadané komunikační situaci). ${ }^{17} \mathrm{~V}$ procesu hodnocení slohové práce funguje vnitřní podmínka: Pokud text první kritérium nesplňuje, je slohová práce hodnocena celkově 0 body (srov. Cermat, 2016a, s. 6; Cermat, 2017, s. 8). Učitelé deklarují největší obavu právě z tohoto kritéria - zvláště v souvislosti s centrálním hodnocením prací - a proto do výuky primárně zařazují ty slohové útvary, jež se mohou objevit u maturitní zkoušky. Ty pak také ve zvýšené míře nacvičují, slovy učitelky Daniely „drtí", podle představ Cermatu (např. Baumgartnerová \& Kapustová, 2013). Lze usoudit, že některé náročnější, typicky středoškolské útvary jsou upozad'ovány např. fejeton. Myšlenková i jazyková (slohová) náročnost obsahu textů se tak snižuje. Zároveň je důležité zjištění, že měřítkem pro sloh ve školní výuce již nemusejí být autority stylistiky (Bečka, Čechová, K. Hausenblas, Havránek, Hoffmannová, Hubáček, Chloupek, Jedlička, Krčmová ad.), nýbrž (anonymně vytvářené) parametry Cermatu.

Požadavky Cermatu stanoví minimální délku maturitní slohové práce na 250 slov (Cermat, 2016b, s. 11). To se také opakovaně spolu s kritérii

17 V každém ročníku maturity toto kritérium vyvolává kontroverze, jež vedou k řadě odvolání proti výsledku hodnocení - situaci učitelé v praxi pochopitelně pečlivě sledují: „[...] viz ta kauza opravy zpráva nezpráva [...], to hodnocení tedy bylo víc než diskutabilní." (Naděžda). 
hodnocení objevuje ve výpovědích dotazovaných učitelů. Řada z nich nacvičuje požadovanou délku závěrečné práce ve vyučování tak, že od žáků požaduje slohové práce o cca 250 slovech i u běžných slohových prací. Není výjimkou, že učitelé s tímto rozsahem pracují již od 1. ročníku:

Dříve psali přece jenom delší práce, takže ted' je to těch 250 slov, protože nemá cenu je učit víc [sic! - pozn. S. Š.]. (Boris)

S čím mám problém, je rozsah. To je zvrácenost, že my je u... nebo oni jim předkládají, napište vypravování na dvě stě padesát slov. To nejde! Nemůžu př́iběh vystavět na dvě stě padesáti slovech. To stejné úvahy. Takže s tím mám problém, a proto taky svým studentům říkám, že to je hodně relativní. (Irma)

Na uvedené výroky lze pohlížet tak, že maturitní zkouška může být pro některé učitele (zvláště na gymnáziích) příčinou pochybování o jejím smyslu, o způsobu didaktické práce s obsahem ze strany Cermatu, o práci nad rámec úrovně maturity. Učitelé jsou požadavky maturity stavěni do situace, kdy se musejí vyrovnávat s otázkou, jakým způsobem didakticky transformovat obsah a zůstat věrni požadavkům kladeným na dobrý sloh a zároveň požadavkům maturitní zkoušky. Tato rozpolcenost může představovat vnitřní rozpor i pro zkušeného praktika, natožpak začínajícího učitele. ${ }^{18}$

K psaní slohové práce i v běžné výuce naši respondenti používají zadání minulých ročníků maturit, což lze také do určité míry označit za nácvik zkouškových strategií, nebot' cílem je primárně žáky seznámit se způsobem zadání slohové práce a nacvičit práci s ním,

protože když jim dám svoje téma, tak oni budou zvyklí na klasická témata, kdežto Cermat tam dává takové ty úryvky a takové. (Boris)

Někteří oslovení učitelé již od 1. ročníku opravují slohové práce podle jednotných kritérií hodnocení, ve 4. ročníku jsou žáci všech dotazovaných učitelů s hodnoticí tabulkou velmi dobře obeznámeni. Jednotná kritéria někteří oslovení učitelé vnímají jako obohacení vlastní praxe, protože stanovila, čeho si při hodnocení slohové práce všímat, příp. poskytla strukturu komentářům k pracím:

Od okamžiku, kdy je státní maturita, ten můj komentář má víc strukturu. (Naděžda)

18 Toto tvrzení můžeme potvrdit nejen z kontaktu s mnoha středoškolskými učiteli - kolegy ale i z práce se studenty učitelství v seminářích didaktiky na PedF UK, tedy učiteli budoucími. 
Ten systém je docela přínosný, že třeba i začínajícím učitelům to dává docela dobrý klíč, na jaká všechna kritéria se v té státní maturitě nebo v té slohové práci zaměřit [...] nějak to roztř́ídit a zvlášt' zhodnotit, je docela dobrá věc. (Michal)

Rovněž alespoň do určité míry sjednotila hodnocení prací třeba v rámci učitelského sboru. Někteří učitelé ČJL, stejně jako jejich kolegové-učitelé cizích jazyků, si tedy uvědomují různost kritérií a začínají je diferencovaně používat při zpětné vazbě pro žáky i v běžné výuce.

Respondenti se v rozhovorech opakovaně dotýkali návratu k centrálnímu hodnocení slohových prací. Názory najdeme z obou stran - někteří považují centrální hodnocení za spravedlivější:

Takže ano, at' to jde k centrálním hodnotitelům, at' je to spravedlivé, a pokud prostě ty děti nedokáží napsat souvislý text o dvě stě padesáti slovech, tak prostě nemají mít maturitu (Radka);

jiní se k němu staví odmítavě - argumenty shrnuje tato výpověd:

Když se to bude takhle anonymně opravovat někde, prostě nějakej ouřada zaplacenej, teda náš kolega, pardon, bude sedět v Cermatu a bude to opravovat, tak tam prostě není ten lidský faktor a v tom obrovském množství silně pochybuju, že se někdo bude nad tím hlouběji zamýšlet. A já si myslím, že my se máme hlouběji zamýšlet nad některými věcmi. (Patricie)

Největší obavu z centrálního hodnocení písemných prací dotazovaní učitelé mají u žáků se speciálními vzdělávacími potřebami - právě „lidský faktor“ zde podle nich hraje rozhodující roli. To lze převést i na zpětnou vazbu, která v této chvíli chybí, protože opravené práce se do škol nevracejí. Přitom zpětná vazba, jak z rozhovorů vyplynulo, je pro učitele důležitá - výsledky maturit totiž analyzují (jedna z vyučujících se dokonce tématem zabývala ve své kvalifikační práci na vysoké škole) a příp. na ně reagují v rámci výuky. Pokud by se ohodnocené práce vracely do škol, mohly by posloužit jako cenná reflexe nejen pro žáky, ale především pro učitele - o to cennější, že pochází od externího subjektu. Jen tak by mohla slohová práce plnit svou funkci praktickou, formativní i vzdělávací (srov. Čechová, 1998, s. 155-156).

V souvislosti s centrálním hodnocením slohových prací se rovněž vrací základní otázka, a to je hodnocení originality a osobitosti textu (problém reflektovaný také v odborném tisku - srov. mj. Rysová, 2013/2014). To učitelům i přes drobné úpravy v kritériích zásadně chybí: „Prostě je tragédie, 
když já žákům říkám - a vycházím z materiálů Cermatu -, že prostě originalita se opravdu víceméně neočekává." (Jaromír). Z vlastní praxe i dotazování mezi našimi respondenty víme, že učitelé žáky od tvořivých, originálních a osobitých řešení pro maturitní slohovou práci přímo odrazují - a lze se domnívat, že se to $\mathrm{v}$ různé míře přímo odráží také ve vyučovací praxi.

Kombinací všech zmíněných faktorů je možno dojít k závěru, že na střední škole může vlivem současné podoby maturitní zkoušky docházet k poměrně zásadnímu zúžení cílů komunikačně-slohové výchovy. Jak již sám název předmětu (výchova) napovídá, nejde jen o naučení slohu, nýbrž o rozvíjení slohových schopností (Čechová, 1998, s. 16). Cílem komunikačně-slohové výchovy není jen vypěstování schopnosti vytvářet kultivovaný jazykový projev adekvátní funkci a komunikační situaci, ale též rozvoj žákovy osobnosti v oblasti charakterové, postojové, hodnotové, emoční atd. směrem k tvořivosti, estetice, fantazii apod. (srov. Čechová, 1996/1997, 1998; Čechová \& Styblík, 1998). Psaní je jedna z nejkomplexnějších aktivit, kterou žáci ve vyučování vykonávají, nebot' vyžaduje zapojení složitých a rozmanitých kognitivních procesů a využití sociálních a jazykových dovedností a znalostí (Myhill et al., 2012a, b). To však podoba ani hodnocení slohové části maturitní zkoušky $\mathrm{v}$ této chvíli nezohledňují, čímž jsou v přímém rozporu s požadavky didaktiky českého jazyka a smyslem slohového vyučování vůbec. Je-li výuka psaní zploštěna na nácvik předepsaných formátů, nelze očekávat, že by rozvoj psaní plnil popsaný cíl a že by zkouška skutečně ověřovala to, co se od ní očekává.

\subsection{Složka literární}

Debata o podobě literární výchovy (stejně jako jazykové složky předmětu) se vede již více než století.

Více než 120 let se volá po menší míre popisnosti, estetickém př́stupu, estetickovzdělávací povaze literární výchovy, př́mé čtenářské zkušenosti s textem, zaměření na vlastní literární dílo, po přesunu těžiště od literární historie k živému dílu, po výchově čtenářủ, po zkušenosti a vhledu, po výchově slovesným uměním (Hník, 2015, s. 44).

I podstatná většina učitelů $\mathrm{z}$ našeho vzorku se $\mathrm{k}$ tomuto pojetí přihlásila.

Podoba ústní části maturitní zkoušky je s výše uvedenými tezemi současné didaktiky literatury ve zdánlivém souladu, obecně totiž prosazuje komunikační pojetí práce s literárním textem. $\mathrm{V}$ tomto směru se k maturitní zkoušce naši respondenti vyjadřovali pozitivně: 
Já si myslím, že ta současná maturitní zkouška, ta její koncepce je výborná právě v tom, že klade důraz na čtenářské dovednosti a čtenářskou gramotnost. (Patricie) Mně se líbí ta ústní část velmi, protože se mi to zdá nejpodstatnější, pěstovat toho čtenáře, který si nepřečte jenom děj, ale přemýšlí o obsahu té knihy, o interpretaci a umí ocenit formu, styl. To myslím, že ta maturita k tomu nějak asi vede. (Beáta)

Zdá se, že zkoumaní učitelé považují pro svou výuku literatury historiografické pojetí za překonané.

Někteří to dávají do souvislosti se zavedením současné podoby maturitní zkoušky:

Děláme cvičné [maturitní - pozn. S. Š.] pracovní listy a oni si zkouší práci s tím textem. (Jolana)

Tak ústní zkouška je jasná v tom smyslu, že tedy máme seznam děl, máme obecnou strukturu té zkoušky a snažíme se tedy přiblížit ta literární díla ze všech stran těm studentům. A ne jenom pokud jde o ty body, které ta obecná struktura nabízí, ale ta práce s textem nebo ta analýza toho textu, aby byla nějak zajímavá nebo rozmanitá. (Denisa)

Jiní o tom byli přesvědčeni již před přeměnou maturity:

Hodina v literatuře bez literatury pro mě moc nemá smysl. (Darina)

Ta literární část se jaksi zcela shoduje s tím, co já chci v té výuce, $\mathrm{k}$ čemu směřuji, takže to neberu jako př́pravu k maturitě, ale beru to zkrátka a dobře jako rozvoj toho studenta a jako př́ležitost, kdy si spolu povídáme o literatuře. A to je v podstatě to, co já chci. (Beáta)

Lze říci, že tzv. státní maturita ukotvila čtenářství jako základ středoškolské výuky literatury a mnozí respondenti toto přijali, př́ip. si minimálně uvědomují, že by přijmout měli: „Dneska mnohem víc s nimi interpretujeme - tam se to tedy změnilo." (Naděžda). Ve výpovědích učitelů sledujeme, že na žáky vyvíjejí intenzivní tlak, aby četli, což se jeví jako značně náročný didaktický úkol. Náročnost ústní zkoušky dle mínění našich respondentů úzce souvisí $\mathrm{s}$ malou čtenářskou zkušeností žáků. Motivace $\mathrm{k}$ četbě tak představuje jednu z hlavních výzev, před níž češtináři stojí. Avšak

pod prací s textem či „rozborem“ díla se ne vždy skrývá interpretace v pravém smyslu slova, ale pouhá rekapitulace děje, doplňování literárněhistorických informací o díle či autorovi bez hlubšího tázání se po smyslu textu. Zážitek z textu 
a výchova ke čtenářství jsou do současné podoby literární výchovy zahrnuty jen okrajově. K umělecké povaze literárního díla a jeho estetické funkci je často pouze odkazováno v rámci faktografického výkladu (Hník, 2015, s. 51).

Jak lze usoudit z výpovědí učitelů v našem vzorku, k témuž bohužel v současné chvíli vede i formát ústní maturitní zkoušky (proto jsme soulad mezi maturitou a didaktikou literatury výše označili jako „zdánlivý“). V jejím prủběhu se pro ni totiž vyžaduje jednotná struktura:

a) charakteristika uměleckého textu je tvořená třemi částmi (téma, kompozice, literární druh a žánr; vypravěč / lyrický subjekt, postavy; jazykové prostředky);

b) charakteristika neuměleckého textu tvořená dvěma částmi (porozumění textu, charakteristika komunikační situace; funkčněstylové charakteristiky textu, jazykové prostředky);

c) k uměleckému textu náleží ještě literárněhistorický kontext díla.

Všechny tyto oblasti dle oficiálních požadavků Cermatu musejí být během patnáctiminutové ústní zkoušky pokryty. Jak dotazovaní učitelé vypovídají, toto pojetí zkoušky je nutí spíše k analýze či rozboru díla namísto jeho interpretace, a to nejen u zkoušky samé, ale i ve výuce:

Co se týká potom těch otázek, tam se přiznám, že už vlastně to ústní zkoušení [v běžné výuce - pozn. S. Š.] je výrazně ovlivněno tou maturitní zkouškou. Protože já bych se samozřejmě ráda ptala třeba na dojem z díla, úvahu nad dílem. Ale zároveň vím, že já u toho svého zkoušení se prostě musím zeptat na literární druh, literární žánr, charakteristiku postav, hlavní motivy; takže vlastně jako by u toho ústního už se snažím jim dávat i ty otázky, které potom následují u maturity. A to je vlastně učím od prváku. (Barbora)

Tam se vlastně moc nepočítá s tím, že by někdo ti ten prožitek se snažil sdělit. Pokud tam je nějaké dítě, které $v$ tom díle něco vidí, působilo to na něj a je to takový ten intuitivní čtenář, tak si zas myslím, že moc u té maturity prostor nemá. (Jolana)

Takže bohužel ta maturita je svým způsobem nuda dneska, protože posloucháš stejné otázky, stejné odpovědi, ty děti jdou v tom průměru, to znamená vyhovět, takže tam odříkají určité věci, které se naučily, byt' tu knížku třeba nečetly. [...] Protože ta literatura, prostě to není předmět. Souvisí to s uměním, souvisí to se zkušenostmi, vnímáním a tak dále. Ale to se dost právě dobře obodovat nedá. (Sabina) 
Z odpovědí by bylo možné vyvodit, že zde narážíme na stejný problém jako v případě slohové práce - výchovná či, chceme-li, duchovní stránka výuky je oslabena. Učitel je od pravého smyslu čtení literárního textu ve výuce, tj. skutečné interpretace působení textu na čtenáře v širokých souvislostech, nastavením maturitní zkoušky nucen k literárně-teoretické analýze. To však primární cíl vnímání literárního textu není.

V rámci našeho výzkumu se však ukázala malá skupina učitelů, kteří jsou si natolik vědomi popsaných cílů literární výchovy, že se s tímto stavem nespokojují:

Samozřejmě se je snažíme vést nejen teda k analýze toho textu - žánrové, druhové, analýzu vypravěče, způsobu vyprávění a tady těch literárních pojmů, které ta osnova maturitní zkoušky akcentuje, ale snažíme se je trošku vést i $k$ takovému tomu zážitkovému vyučování, aby o té knížce dokázali hovořit trošku kreativním způsobem. (Berta)

Z výpovědí všech respondentů jasně vyplývá, že obsah výuky literatury je ve velké míře určován školním kánonem literárních děl, a to již od 1. ročníku. Jednak oslovení učitelé soustředí intenzivní pozornost právě na díla zahrnutá do kánonu:

Pokud řekne, já ted' čtu Pratchetta, a rozpovídá se na minutku, co je námětem a co ho na tom zaujalo, tak jako řeknu dobře, ale nezapomenu poznamenat, že prostě k sobě si nemůžu napsat, že má splněný čtenářský deník, protože to nemáme v kánonu. Takže jako nejde s pětkou, ale mám u sebe, že kánon ne, deník nemá splněno. (Barbora)

a jednak také žáci svou vlastní četbu vybírají podle kánonu: „Nekánonová díla takzvaně vypadají a studenti je moc neakceptují, oni skutečně pragmaticky jedou na tu dvacítku." (Sabina).

Respondenti také kritizují absenci současné světové i české literární produkce v oficiálně doporučeném obsahu zkoušky (srov. Cermat, 2015). Výpověd' učitelky s nejdelší praxí shrnuje veškeré argumenty: „Já si to troufnu říct, protože já jsem právě ta stará struktura [...] - takhle jsme učili opravdu před 30 lety." (Denisa).

Častým tématem $\mathrm{v}$ rozhovorech byl rovněž počet přečtených literárních děl povinných k maturitě (celkem 20 titulů). Zvláště oslovení učitelé gymnázií toto omezení chápou jako problém, a to opět především $\mathrm{v}$ rovině motivace žáků: 
Ta literatura se opravdu scvrkne na papouškování dvaceti třiceti titulů z kánonu, a to je určitě škoda. Takže k té ústní mám já osobně vlastně největší výhradu, averzi v tom smyslu, jak je podaná. (Naděžda)

Tak v momentě, kdy všichni vědí, že prostě musí za čtyři roky přečíst 20 knížek, což je komické číslo, tak co... Prostě co vy po nich můžete, když oni začnou a rodiče začnou a tak dál, co po nich vlastně chcete. (Jaromír)

Je zřejmé, že motivovat žáky k práci nad rámec požadavků musí být obtížné.

\subsection{Maturita a vyučování}

Jak dotazovaní učitelé odhadují míru vlivu maturity na svou výuku, jsme zjištovali jednou otázkou pomocí škály od 1 - vůbec neovlivňuje po 5 - ovlivňuje zásadně: průměr odpovědí je 3,43. Žádný z učitelů nevybral možnost 1 , rozložení u ostatních možností bylo poměrně rovnoměrné, a to i co do výběru odpovědi podle typu školy. Lze tedy usoudit, že vliv maturity na vyučování připouštějí všichni oslovení učitelé, a nezáleží při tom na typu školy, v níž působí. Liší se však mezi sebou mírou tohoto vlivu.

U učitelů, kteří učili i před zavedením nové podoby maturitní zkoušky, jsme zkoumali, nakolik pocit'ují proměnu způsobu výuky oproti starému modelu. Na škále 1 - vůbec neproměnila až 5 - proměnila zásadně jsme zaznamenali průměr 2,9. Pouze jeden z respondentů vybral možnost 1 , ostatní odpovědi se pohybovaly na hodnotách kolem možnosti 3. Možnost 5 nevybral žádný z respondentů. Na tyto údaje lze nahlížet tak, že i zkušení praktici pocitují vliv maturitní zkoušky na svou práci, ale možná jim pedagogická zkušenost dává větší prostor k méně spoutanému plánování a řízení výuky, než je tomu u učitelů s menší praxí (což ostatně odpovídá výsledkům výzkumů, které ukazují, že liberálnější vyučovací styl mají učitelé s delší vyučovací praxí, zatímco začínající učitelé tíhnou spíše ke stylu exekutivnímu - srov. např. Au \& Carroll, 1997, nebo Hübelová, 2009).

Z rozhovorů zřetelně vyplývá, že očekávané výstupy a konkrétní obsah výuky jsou v dnešní střední škole udávány především katalogem požadavků $\mathrm{k}$ maturitě, obsah katalogu je přetavován do ŠVP a do výuky. Rámcový vzdělávací program funguje pouze jako jakési vzdálené kurikulum $\mathrm{v}$ teorii, $\mathrm{k}$ jehož očekávaným výstupům se učitelé v praxi již nevracejí. Školní vzdělávací programy představují tematické plány, zásadně ovlivněné katalogem požadavků k maturitě, a časové harmonogramy. RVP a ŠVP ve svých výpovědích zmínil jediný vyučující (a to pouze ve smyslu, že je máme). Význam katalogu ilustrují tyto výroky: 
Ty seznamy nám přišly natolik závažné, že jsme změnili tematické plány. Jestliže chceme, aby naši studenti byli úspěšní, aby měli pěkné maturitní vysvědčení, aby tomu odpovídaly znalosti, tomu, co předvádějí, tak se samozřejmě musíme aspoň částečně přizpůsobit těmhle seznamům. (Berta)

Ty požadavky jsou jednoznačně dané tím katalogem požadavků, který dává ministerstvo. Takže tam nedochází k nějakým diskusím, co učit nebo neučit, respektive ten základ je daný, pak můžeme diskutovat o té nadstavbě. (Darina)

Já se snažím všechno naroubovat na tu maturitu. Ten tematický plán. Protože v tom plánu máme udělat třeba rozdělení jazyků ve čtvrtáku nebo vývoj češtiny. To prostě vezmu letem světem a pak stejně dělám věci k maturitě. Ale nadepíšu, abych splnila plán, vývoj jazyka a pak dělám věci k maturitě, no. Ale to neříkám nahlas. (Daniela)

Toto upřímné vyjádření učitelky Daniely poukazuje na vznik jakési „šedé zóny" v praxi některých učitelů - něco jiného deklarují kontrolním orgánům a vedení školy a něco jiného provádějí ve vyučovací hodině.

Dle většiny dotazovaných učitelů, a to z gymnázií i SOŠ, došlo celkově k redukci obsahu:

Učím toho méně. Musí se toho učit méně, protože v podstatě musí se část věnovat přípravě na tu maturitu, a myslím si, že spousta zajímavých projektů tím pádem odpadne, protože se na ně prostě nedostane. (Jaromír)

Redukce obsahu však souvisí s celou řadou dalších činitelů, nikoliv jen s maturitní zkouškou, jak by se z Jaromírovy promluvy mohlo zdát; změny jsou do jisté míry determinovány typem školy (na SOŠ více) nebo individuálními charakteristikami žáků:

Kdybych učila v uvozovkách elity, chytřejší děti, tak by mě třeba vůbec (maturita) neovlivnila, protože bych jim prostě řekla: Tak, pokud si chcete procvičit didaktické testy, koukněte se na web tam a tam a tam, tam de facto najdete úplně všechno. Takže ono jde taky jako o inteligenci a př́stup těch studentů. Já to... ano, já to dělám proto, protože vím, že oni jsou absolutně neschopní to udělat sami a zcela automaticky, takže to si myslím, že tak jako velmi ovlivňuje - koho učíš, jakou sortu dětí. (Barbora)

Významný faktor ve změnách obsahu tedy představuje také pocitovaná klesající úroveň středoškoláků. $Z$ rozhovorů lze postihnout přímou úměru: čím nižší kognitivní kapacitu žáků učitelé pocitují, tím více redukují obsah. 
K redukcím však nedochází organizovaně, na celostátní úrovni, ale spíše intuitivně dle uvážení učitelů dané školy.

Na druhou stranu ale existuje úzká skupina učitelů, kteří se nenechávají formálními požadavky svázat, odmítají průměr udaný maturitní zkouškou, kladou si vyšší cíle a dělají i věci nad rámec (takřka výlučně jde o učitele gymnázií):

Já vím, k čemu směřuju, ale nenechávám se tím svázat. Nevnímám to jako něco, že bych nemohla si najít čas udělat něco, co třeba s tou maturitou vůbec nesouvisí. $\mathrm{Ne}$, jsou takové hodiny prostě. Rozšířené hodiny nebo i sem tam, když se naskytne... Taky podle toho, jak časově na tom jsem $v$ těch hodinách - klidně děláme díla, která vůbec nejsou v kánonu a vůbec se k maturitě neváží. (Barbora)

Jednoznačně chci delší texty a od začátku prvního ročníku jim vždycky ř́kám, že prostě úvaha se nedá napsat na 250 slov - že to jsou úvažičky až pidiúvažičky, takže jednoznačně píšou delší slohy. Já s nima píšu i klasické velké seminárky. (Irma)

Rozhodně nenacvičujeme slepě jenom ty požadavky té státní maturity - řekla bych, že tím bychom snížili tu kvalitu teda velmi tvrdě na gymnáziu. [...] Prostě mám ty šikovné děti a mohu si zachovat tu náročnost a takovou tu určitou šíri. (Naděžda)

To vše se děje při stálém vědomí požadavků maturity - bud' jako vymezení se proti ní (až do formy jakéhosi vnitřního souboje vlastního přesvědčení s autoritou, formálním pokynem), anebo jako doplnění toho, co maturita požaduje.

\section{$4 \quad$ Diskuse výsledků}

Nová kultura vyučování a učení je postavena na základech pedagogického, psychologického a (oborově)didaktického konstruktivismu (Janík, 2013). Ten klade do středu vyučování i učení žáka a jeho perspektivu, nebot' považuje učení za osobní konstrukt každého individua. Myšlenky konstruktivismu též stály $\mathrm{v}$ pozadí kurikulární reformy, během níž byly zavedeny Rámcové vzdělávací programy: mj. individualizace učebních procesů podle potřeb žáka, kognitivní aktivizace žáků, zavádění autentických učebních úloh, generativní řešení problémů, podpora metakognitivních procesů atd. (Janík et al., 2013, s. 138). Z prezentovaných zjištění však lze usoudit, že ideje kurikulární reformy jsou s jednotnou maturitní zkouškou v rozporu. Ačkoliv maturitní katalog není hlavním kurikulárním dokumentem, předepsané kurikulum zastínil. Určující pro obsah výuky je hodnocené kurikulum 
(srov. Walterová, 1994) stanovené v maturitních katalozích, příp. dalších materiálech vydávaných Cermatem (např. Baumgartnerová \& Kapustová, 2013, nebo Cermat, 2015).

Centralizací hodnocení slohových prací i stanovením jednotné formy ústní zkoušky byla individualizace, autenticita a heterogenita ve výuce ČJL omezena, přitom kognitivní úroveň středoškoláků naopak přímo vybízí k postupu opačnému. Nastavení maturitní zkoušky je též, dle výpovědí učitelů, v kontradikci s požadavky současné didaktiky českého jazyka a literatury. Pohledem sledovaných hypotéz Aldersona \& Wallové (1993) lze tedy konstatovat, že maturita ovlivňuje vyučování, konkrétně čemu učitelé vyučují i jakým způsobem vyučují. Nastavení maturitní zkoušky ovlivňuje všechny učitele, ale každého vždy pouze v některých aspektech. Jejich zorné úhly se liší, velmi záleží na jejich vlastním pedagogickém přesvědčení a hodnotách, o nichž se domnívají, že by měli svým žákům zprostředkovat.

Z výpovědí dotazovaných učitelů vyplývá, že zvláště na gymnáziích a teoretičtějších SOŠ zkouška snižuje motivaci žáků ke studiu, nebot' limity jsou v jejich očích nastaveny př́liš nízko. Naopak pro praktičtější SOŠ představuje státní maturita z českého jazyka nesnáz, protože žáci nejsou primárně motivováni ke studiu teoretických předmětů. Na nutnost diferenciace středoškolského vyučování češtiny podle typů škol upozorňovala např. Čechová (1998, s. 107). Jednotná zkouška pro všechny středoškolské obory se tak jeví spíše jako problematická, čímž narážíme na předmět mnohých debat, které provázejí podobu maturity od samého začátku. $\mathrm{V}$ tomto smyslu tedy maturitní zkouška ovlivňuje širřku, míru i hloubku vyučování, u některých vyučujících rovněž sled učiva.

Z rozhovorů s učiteli vyplývá, že součástí př́ípravy na maturitní zkoušku z ČJL se stala poměrně rozsáhlá př́íprava v oblasti zkouškových strategií, jež u původního modelu nutná nebyla. Respondenti vypovídali, že u původní maturity také hojně před zkouškou opakovali, avšak jednalo se spíše o návrat k obsahu, nikoliv o nácvik strategií řešení různého typu úloh.

Výuka jazyka a literatury zahrnuje rozvoj dovedností, z nichž mnohé ani testovat nelze. Maturita tak v jazykové složce nutně musí setrvávat na tradičních (základních) lingvistických disciplínách (na rovině langue), přitom moderní didaktika i kurikulum akcentují také rozvoj v oblasti disciplín roviny parole. Podobně ve výuce literatury jednotné zkušební schéma pro ústní 
zkoušku podvazuje tvořivou recepci uměleckého i neuměleckého textu - motiv literárně-teoretické analýzy literárního díla namísto interpretace pod vlivem současného nastavení zkoušky se v rozhovorech objevoval opakovaně. Totéž se týká standardizované slohové práce. Žáci sice napíší více slohových prací (mnozí učitelé $\mathrm{z}$ našeho vzorku např. přijímají slohové práce kdykoliv během roku, někteří vypověděli, že žáci ve 4 . ročníku napíší šest až osm prací), avšak jde o psaní mechanické, naplňující předepsané matrice. Jeho cílem není hledání kreativních řešení, invenčních přístupů, originality či osobitosti textu, nýbrž nácvik požadovaných forem. Všechny tyto faktory mohou mít významný vliv na míru naplňování cílů výuky mateřštiny, zvláště pak cíle formativního.

Limitem předložené studie je velikost vzorku respondentů, výsledky výzkumu proto nelze generalizovat. Jejím cílem bylo spíše ukázat, jaké jevy se ve spojitosti s maturitní zkouškou ve školské praxi vyskytují, resp. jaké problémy učitelé řeší. Témata, která jsme v tomto příspěvku nabídli, mohou posloužit jako zdroj pro další výzkumy.

Omezením této studie je rovněž absence učitelů středních odborných učilišt' s maturitními obory, jejichž reakce na náš e-mail s výzvou k účasti ve výzkumu byla nulová. Jejich pohled by rozhodně měl být zkoumán, nebot' žáci středních odborných učilišt', jak z maturitních dat víme, jsou co do neúspěchu u zkoušky nejrizikovější skupinou.

Rovněž si uvědomujeme, že se ocitáme uprostřed kontroverzního tématu. Úmyslem tohoto prríspěvku není jakkoliv agitovat ve prospěch tzv. státní maturity či proti ní. Vzhledem k tomu, že je na maturity neustále soustředěna velká pozornost $\mathrm{z}$ mnoha stran, vycházeli jsme z potřeby do debaty přispět určitými výzkumnými zjištěními.

\section{Závěr}

Maturitní zkouška má v našem vzdělávacím systému velmi významnou roli. Výsledky našeho výzkumu nasvědčují tomu, že i v českém kontextu mohou mít rozhodné zkoušky, mezi něž maturita patří, na vyučování poměrně zásadní vliv, a to v různých formách. Tím by se potvrdila zjištění zahraničních výzkumů (např. Andrews, Fullilove, \& Wong, 2002, nebo Cheng, 2005), která poukazují na tentýž fenomén. 
I u nás v ústředí veškerých těchto projevů stojí učitel a jeho pedagogické přesvědčení. Výpovědi našich respondentů lze číst tak, že jsou na změny v koncepci maturity poměrně citliví, bedlivě je sledují a reagují na ně. Lze tak usoudit, že washback maturitní zkoušky (a zde míníme mikropohled, tedy vliv na vyučování) je potenciálně značný. Z představených výsledků vyplývá, že nastavení maturity se do vyučování českého jazyka promítá metodicky i obsahově, v př́ípadě vyučování literatury a komunikačně-slohové výchovy by obecně bylo možné hovořit o vlivu koncepčním. Ve vyučování literatury akcentuje komunikační pojetí literární výchovy, v případě komunikačně-slohové výchovy výsledky našeho výzkumu naznačují odklon od funkční stylistiky směrem k vázanému slohu (srov. Čechová, 2017, s. 224).

Podoba maturitní zkoušky z českého jazyka a literatury může působit na to, čemu učitelé vyučují a jak dané učivo žákủm zprostředkovávají. U některých učitelů mohlo dojít k redukci obsahu, ke změně postavení některých partií učiva ve vyučování nebo ke změně uvažování o obsahu. Středoškolští češtináři do určité míry plánují výuku dle podoby závěrečného výstupu a mohou mu přizpůsobovat i cíle a obsahy jednotlivých celků učiva. Hypotézy dle Andersona a Wallové (1993), které jsme stanovili jako tematický rámec výzkumu, můžeme i na základě našich výsledků pokládat za platné - podoba maturity vliv na výuku českého jazyka a literatury má.

Úkolem tohoto příspěvku není zabývat se důvody, které vedly k centralizaci maturitní zkoušky, nicméně od doby, kdy se začalo uvažovat o její reformě, se hovořilo o jejím certifikačním charakteru. Diskusi však bohužel opanovaly formální aspekty zkoušky namísto otázek základních, tedy koncepčních (srov. přehled odborné literatury v úvodu). Nijak nebyl řešen základní problém jakéhokoliv standardizovaného testování, totiž že nemůže postihnout mnohé podstatné cíle (nejen jazykového a literárního) vzdělávání: kreativitu, schopnost kritického myšlení, sociální kompetence atd. Český jazyk a literatura je předmět $s$ výrazným formativním akcentem, aktualizovaným o to více, že kurikulum směřuje ke kompetencím. Výsledkem se zdá být rozpor mezi kurikulem, které zdůrazňuje hlediska v podstatě netestovatelná, a výstupem ze střední školy, který očekává zvládnutí ověřitelných ukazatelů.

Před zavedením tzv. státní maturity nebyl nijak zkoumán stav středoškolské výuky (nejen ČJL), možný vliv nové podoby zkoušky na výuku nebyl nijak reflektován. Tyto dvě entity však, jak se ukazuje, nelze oddělit, jde o komplexní otázku. Narážíme na dva různé pohledy. Na jedné straně již dříve 
někteří odborníci upozorňovali, že „maturit nelze dříve modernizovat, dokud nebyla zmodernizována předchozí výuka, jež se maturitami zakončuje. Začínat opravu školství u závěrečných zkoušek znamená stavět dům od střechy" (J. Štech v r. 1931, cit. podle Skalková, 2000, s. 273). Na druhé straně však stojí argument, že pokud bychom měli čekat, až se zlepší výuka, mohli bychom čekat velmi dlouho, nebot' setrvačnost ve školství je značná. Použít výstup jako nástroj vzdělávací politiky ve smyslu využití maturity ke změně středoškolské výuky se proto jeví jako logické a odůvodnitelné. Je však třeba důkladně promyslet, jakou podobu standardizovaná zkouška bude mít, aby požadovaného efektu bylo dosaženo. Výchozím bodem by měl být vztah mezi tím, co a jak se testuje, a tím, co a jak by se mělo vyučovat. Zároveň by se mělo zvažovat, jaká forma přípravy na zkoušku by byla nejvhodnější a jak by taková efektivní př́prava mohla být podpořena (Green, 2013). „(...) návrhy testování (by) neměly navozovat jakousi skrytou nedůvěru vůči hodnocení vyučujících (jejich kolektivů či komisí) a jejich poctivého úsilí a odpovědnosti“ (Skalková, 2000, s. 280), jinak je podvazována pedagogická iniciativa učitelů. I naši respondenti vnímají „stahování“ zkoušky různými nařízeními a předpisy. Nabízí se proto zvážit míru direktivního řízení zkoušky i jejího hodnocení, aniž by se opouštěl cíl sjednocovat požadavky a hodnocení (srov. Čechová, 2017, s. 225).

Byl-li cíl testování zlepšit výuku na středních školách, pak by měla být získaná data využívána k hlubším analýzám či reflexi vzdělávání. Důvěryhodnost zkoušky podrývá, pokud jsou maturitní data úzkostlivě tajena a musí vznikat veřejné iniciativy, aby byla zveřejněna (např. Maturitní data - odtajněno). Validitě zkoušky by proto napomohla nejvyšší možná transparentnost zkušebního procesu, a to jak před zkouškou, tak především po ní. Příkladem $\mathrm{v}$ tomto může být slovenský Národní ústav certifikovaných měření vzdělávání (NÚCEM), v jehož gesci na Slovensku centrálně zadávaná testování jsou a jenž každoročně analýzy výsledků zveřejňuje. Je tak možno se dozvědět např. úspěšnost dle pohlaví, druhu školy, délky studia, testovaných oblastí, zřizovatele, kraje, zkoumá se též korelace klasifikace z předmětu a úspěšnosti u maturitní zkoušky atd. ${ }^{19}$

Studie naznačuje otázky, které vyžadují odpovědi před zavedením jakéhokoliv standardizovaného testu do průběhu školní docházky. To se týká také aktuálních jednotných přijímacích zkoušek (srov. Štěpáník, 2016/2017).

19 Srov. http://www.nucem.sk/sk/maturita. 
Učitelství je práce tvůrčí a (nepromyšlené či politicky zapř́ičiněné) zatěžování školského systému standardizovanými testy může představovat riziko (srov. situaci v Polsku - Pieniążek, 2016, s. 118). Je žádoucí, aby se washback efekt jakýchkoliv zkoušek stal předmětem extenzivní výzkumné reflexe, jejíž výsledky budou odborníky prezentovány ve veřejné i politické debatě.

\section{Literatura}

Alderson, J. Ch., \& Wall, D. (1993). Does washback exist? Applied Linguistics, 14(2), 115-129.

Andrews, S., Fullilove, J., \& Wong, Y. (2002). Targeting washback: A case study. System, 30(2), 207-223.

Au, K. H., \& Carroll, J. H. (1997). Improving literacy achievement through a constructivist approach: The KEEP demonstration classroom project. The Elementary School Journal, 97(3), 203-221.

Baumgartnerová, G., \& Kapustová, A. (2013). Jak na to: písemná práce z českého jazyka. Praha: Cermat.

Bílek, P. A. (2001/2002). Rýžujeme na maturitě z českého jazyka 1: literatura. Český jazyk a literatura, 52(1-2), 6-10.

Cermat. (2014). Katalog požadavků zkoušek společné části maturitní zkoušky: český jazyk a literatura. Praha: Cermat.

Cermat. (2015). Sdělení ředitele Centra - Seznam literárních žánrů a autorů k didaktickému testu $z$ českého jazyka a literatury. Praha: Cermat.

Cermat. (2016a). Ciskom: 3. Komplexní jazyková zkouška. 3.1 Český jazyk a literatura. 3.1.2 Hodnocení písemné práce - český jazyk a literatura. Praha: Cermat.

Cermat. (2016b). Ciskom: 3. Komplexní jazyková zkouška. 3.1 Český jazyk a literatura. 3.1.1 Metodologie písemné práce - český jazyk a literatura. Praha: Cermat.

Cermat. (2017). Metodický materiál pro hodnotitele písemných prací z českého jazyka. Odborná príprava centrálních hodnotitelů PP: MZ 2017. Praha: Cermat.

Čáp, J. (1993). Psychologie výchovy a vyučování. Praha: Karolinum.

Čechová, M. (1996/1997). Tvořivostí učitelů k tvořivosti žáků? Český jazyk a literatura, 47(3-4), 68-81.

Čechová, M. (1998). Komunikační a slohová výchova. Praha: ISV nakladatelství.

Čechová, M. (2011/2012). Zrušíme nejen větné rozbory? Český jazyk a literatura, 62(5), 237-241.

Čechová, M. (2013/2014). Smysl středoškolského studia češtiny ve stínu maturit. Český jazyk a literatura, 64(1), 1-6.

Čechová, M. (2017). Živots češtinou: Nomen omen: Češtinářka - Češka - Čechová. Praha: Academia. Čechová, M., \& Styblík, V. (1998). Čeština a její vyučování. Praha: SPN.

Green, A. (2013). Washback in language assessment. International Journal of English Studies, 13(2), 39-51.

Hník, 0. (2014). Didaktika literatury: výzvy oboru. Praha: Karolinum. 
Hník, O. (2015). Didaktika literatury: od polemických diskursů po formování samostatného oboru. In I. Stuchlíková, \& T. Janík (Eds.), Oborové didaktiky: vývoj - stav - perspektivy (s. 41-66). Brno: MU.

Hrubý, D. (2015). Ta naše maturita česká. Pedagogická orientace, 25(5), 722-726.

Hübelová, D. (2009). Výukové metody a styly učitelů zeměpisu: případové (video)studie. Pedagogická orientace, 19(2), 53-57.

Cheng, L. (2005). Changing language teaching through language testing: A washback study. Studies in Language Testing 21. Cambridge: CUP and Cambridge ESOL.

Cheng, L., Sun, Y., \& Ma, J. (2015). Review of washback research literature within Kane's argument-based validation framework. Language Teaching, 48(4), 436-470.

Chvál, M. (2011). Zamotané problémy maturitní zkoušky. Pedagogika, 61(3), 211-214.

Ibrahim, R. (2013/2014). K ústní zkoušce z češtiny (Máj Karla Hynka Máchy). Český jazyk a literatura, 64(5), 209-212.

Janík, T. (2013). Od reformy kurikula k produktivní kultuře vyučování a učení. Pedagogická orientace, 23(5), 634-663.

Janík, T., Slavík, J., Mužík, V., Trna, J., Janko, T., Lokajíčková, V., \& Zlatníček, P. (2013). Kvalita (ve) vzdělávání: obsahově zaměřený př́stup ke zkoumání a zlepšování výuky. Brno: MU.

Jedlička, R. (2003). Bude reformovaná maturita zkouškou dospělosti i pro učitele? Pedagogika, 53(3), 249-252.

Jeník, P. (2008/2009). Přežijeme novou maturitu? Český jazyk a literatura, 59(3), 135-138.

Kostečka, J. (2001/2002). Návrh nové koncepce výuky předmětu český jazyk a literatura. Český jazyk a literatura, 52(9-10), 209-212.

Kostečka, J. (2012/2013). Hodnocení slohových prací středoškoláků, včetně maturitních. Český jazyk a literatura, 63(3), 134-145.

Kot'a, J. (2011). Úvaha o maturitě anebo cesta mezi vědou a politikou. Pedagogika, 61(2), 113-116.

Krejčová, L. (2009). Význam učitelů a školního prostředí pro motivaci dospívajících při studiu ve stř̌edních školách. Studia paedagogica, 14(2), 85-106.

Lederbuchová, L. (2002/2003). Literatura, učivo a didaktická interpretace uměleckého textu. Český jazyk a literatura, 53(2), 68-75.

Lederbuchová, L. (2010). Literatura ve škole. Plzeň: ZČU.

Lippmann, K. (2010/2011). Dokážeme to? Český jazyk a literatura, 61(3), 131-133.

Lippmann, K. (2011/2012). Byla to ještě maturita? Český jazyk a literatura, 62(2), 76-81.

Machová, S. (2003/2004). Studium českého jazyka na gymnáziích a středních odborných školách. Český jazyk a literatura, 54(3), 138-139.

Maňák, J., \& Švec, V. (2003). Výukové metody. Brno: Paido.

Myhill, D. (2012a). Grammar for writing? The impact of contextualised grammar teaching on pupils' writing and pupils' metalinguistic understanding. End of grant report. Dostupné $\mathrm{z}$ http://www.researchcatalogue.esrc.ac.uk/grants/RES-062-23-0775/outputs/read/ c5bff83b-28d3-4945-8b8c-eb4b4c8406ae

Myhill, D. A., Jones, S. M., Lines, H., \& Watson, A. (2012b). Re-thinking grammar: The impact of embedded grammar teaching on students' writing and students' metalinguistic understanding. Research Papers in Education, 27(2), 139-166. 
Pieniążek, M. (2016). Teaching Polish language and literature in Poland. In M. Pieniążek \& S. Štěpáník (Eds.), Teaching of national languages in the V4 countries (s. 103-134). Praha: PedF UK.

Průžová, H. (2013/2014). Maturitní fórum. Český jazyk a literatura, 64(1), 34-37.

Rysová, K. (2005/2006). Několik postřehů z výuky českého jazyka a literatury na SŠ. Český jazyk a literatura, 56(5), 232-234.

Rysová, K. (2009/2010). Ještě o nové maturitě. Český jazyk a literatura, 60(1), 27-31.

Rysová, K. (2011/2012). Cizincem ve vlastní zemi. Český jazyk a literatura, 62(4), 183-185.

Rysová, K. (2013/2014). Originalita a invence v písemných maturitních pracích. Český jazyk a literatura, 64(2), 76-79.

Shih, C.-M. (2009). How tests change teaching: A model for reference. English Teaching: Practice and Critique, 8(2), 188-206.

Skalková, J. (2000). Maturita - dlouhodobý problém a aktuální výzva. Pedagogika, 50(3), $272-284$.

Soukal, J. (2005/2006). Jak (ne)učit český jazyk a literaturu. Český jazyk a literatura, 56(3), $127-133$.

Soukal, J. (2008/2009). Kánon není jen seznam. Český jazyk a literatura, 59(2), 70-73.

Soukal, J. (2010/2011). Tvorba pracovních listů. Český jazyk a literatura, 61(2), 81-91.

Soukal, J., \& Skalská, I. (2011/2012). Maturitní zkouška 2011. Český jazyk a literatura, 62(1), 29-42.

Šmejkalová, M. (2010). Čeština a škola - úryvky skrytých dějin: český jazyk a jeho vyučování na středních školách, 1918-1989. Praha: Karolinum.

Štěpáník, S. (2016/2017). Co přinesou centrálně zadávané přijímací zkoušky? Český jazyk a literatura, 67(3), 105-111.

Štěpáník, S. (2016). Výuková situace: transformace větného členu na větu a naopak v kontextu větného rozboru. Komenský, 140(4), 30-39.

Štěpáník, S., \& Šmejkalová, M. (2017). Průvodce začínajícího češtináře. Praha: PedF UK.

Tabášek, V. (2007/2008). Několik poznámek k podobě státní maturity z českého jazyka (a literatury?). Český jazyk a literatura, 58(2), 72-75.

Walterová, E. (1994). Kurikulum. Proměny a trendy v mezinárodní perspektivě. Brno: MU.

Zimová, L. (2005/2006). Když se řekne skladba... Český jazyk a literatura, 56(5), 209-214.

\section{Poděkování}

Děkuji Daniele Kloudové, Martinu Chválovi a Martině Šmejkalové za pomoc při přípravě tohoto příspěvku.

\section{Autor}

PhDr. Stanislav Štěpáník, Ph.D., Katedra českého jazyka, Pedagogická fakulta Univerzity Karlovy v Praze, M. D. Rettigové 4, 11639 Praha 5, e-mail: stanislav.stepanik@pedf.cuni.cz 


\title{
Washback of the new school-leaving examination in Czech language and literature on instruction in teachers' statements
}

\begin{abstract}
The aim of this empirical study is to research the washback effects of the new form of the school-leaving examination in Czech language and literature (CLL) on CLL instruction at upper-secondary school. Through the method of semi-structured interviews with sixteen upper-secondary school teachers we researched (1) how (according to the teachers) the form of the school-leaving examination influences CLL instruction at upper-secondary school, and (2) how CLL teachers evaluate the school-leaving examination in CLL and how this evaluation relates to the teachers' approach to instruction and exam preparation. The results indicate that the new school-leaving examination model has brought some positive changes, but in certain aspects it contradicts the demands of current Czech language and literature didactics and declared educational aims of current school as well.
\end{abstract}

Keywords: washback, school-leaving examination, Czech language, instruction, literature, communication and composition, language

Zounek, J., Šimáně, M., \& Knotová, D. (2017). Normální život v nenormální době: základní školy a jejich učitelé (nejen) v období normalizace. Praha: Wolters Kluwer.

Kniha vytváří plastický obraz československého socialistického školství, který se zakládá jak na vzpomínkách pamětníků, získaných metodou orální historie, tak na studiu archivních, mnohdy pro podobné účely dodnes nevyužitých dokumentů. Prezentuje výsledky pedagogicko-historického výzkumu, který proběhl v uplynulých letech. V centru pozornosti stojí vzdělávání učitelů před rokem 1989 a jejich zkušenosti s výukou na základních školách. Pedagogové, kromě (politicky laděných) schůzí ve škole, popisují i svou mimopracovní činnost a volný čas. Doposud poměrně neprobádané téma pak představuje snaha o ateizaci společnosti, $v$ níž měli právě učitelé sehrávat důležitou roli. Pamětníci rovněž podávají svědectví o atmosféře ve školách $\mathrm{v}$ době pražského jara a o tzv. strategiích přežití, prověrkách i postizích, které po něm následovaly, či o období normalizace. 


\section{Př́loha 1}

Výzkumné otázky:

1) Připravujete své studenty specificky/cíleně k maturitě z ČJL, ev. k některé části maturity z ČJL? - Jak?

2) Kdy začínáte $s$ cílenou přípravou k maturitě z ČJL?

3) Kolik času věnujete cílené př́pravě na maturitu z ČJL? (Bylo by možné specifikovat na rovině školního roku / týdne / vyučovací hodiny / týdenní časové dotace předmětu?)

4) Jak připravujete žáky na
a) didaktický test?
b) písemnou práci?
c) ústní zkoušku?

5) Kterou z částí maturitní zkoušky z ČJL považujete za nejnáročnější? - Jak toto zohledňujete ve vyučování?

6) Jak hodnotíte podobu maturitní zkoušky z ČJL, tj. strukturu a obsah? Ohodnot'te jako ve škole (výborný-nedostatečný). - Komentář k některé z částí (didaktický test, písemná práce, ústní zkouška)?

7) Jak hodnotíte náročnost maturitní zkoušky z ČJL vzhledem k tomu, jakou náročnost by měla podle vašeho názoru maturita mít? (velmi snadná spíše snadná - přiměřená - spíše náročná - velmi náročná)

8) Co pro vás znamená maturita?

9) V zrcadle odpovědi na otázku č. 8 - jak moc je pro vás příprava na maturitu důležitá?

10) Jak moc ovlivňuje podoba maturity z ČJL vaši výuku? (K odhadu můžete použít škálu 1 vůbec neovlivňuje - 5 ovlivňuje zásadně.)

11) Jak podoba tzv. státní maturity (nové maturity) z ČJL proměnila vaši výuku (obsah a používané metody a formy) oproti maturitě bývalé? (K odhadu můžete použít škálu 1 vůbec neproměnila - 5 proměnila zásadně.) 
12) Jak moc tzv. státní maturita (nová maturita) proměnila váš způsob př́ípravy žáků na maturitu oproti stavu před zavedením tzv. státní maturity $\mathrm{z}$ ČJL? (K odhadu můžete použít škálu 1 vůbec neproměnila - 5 proměnila zásadně.)

13) Jakýkoliv další komentářr? 